\title{
Banking Industry Consolidation and Market Structure: Impact of the Financial Crisis and Recession
}

\author{
David C. Wheelock
}

\begin{abstract}
The number of U.S. commercial banks and savings institutions declined by 12 percent between December 31, 2006, and December 31, 2010, continuing a consolidation trend begun in the mid1980s. Banking industry consolidation has been marked by sharply higher shares of deposits held by the largest banks-the 10 largest banks now hold nearly 50 percent of total U.S. deposits. However, antitrust policy is predicated on the assumption that banking markets are local in nature, and enforcement has focused on preventing bank mergers from increasing the concentration of local banking markets. The author finds little change over time in the average concentration of local banking markets or the average number of dominant banks in them, even during the recent financial crisis and recession when numerous bank failures and several large bank mergers occurred. Concentration did not increase substantially, on average, in markets where mergers occurred among banks when both the acquiring and acquired banks had existing local offices, though rural markets generally saw larger increases in concentration from such mergers than did urban markets. Although the structures of local banking markets, on average, have changed little since the mid-1980s, deposit concentration has continued to increase at the level of U.S. Census regions. As technology evolves and the costs of obtaining banking services from distant providers fall further, local market characteristics may become less relevant for analysis of competition in banking. (JEL G21, G28, L41)
\end{abstract}

Federal Reserve Bank of St. Louis Review, November/December 2011, 93(6), pp. 419-38.

T

he recent financial crisis and recession produced a sharp increase in the number of commercial bank and savings institution failures in the United States. Mergers of non-failed commercial banks and savings institutions (hereafter "banks") eliminated still more banks, and in total, the number of U.S. banks fell by 12 percent between December 31, 2006, and December 31, 2010. ${ }^{1}$ Over the same period, the share of total U.S. deposits held by the 10 largest commercial banks rose from 44 to 49 percent, continuing a trend that began in the

1 The Federal Deposit Insurance Corporation (FDIC) often resolves
bank failures by arranging mergers of failed institutions with other
banks. These are referred to as "assisted" mergers. Mergers that
do not involve failed institutions are referred to as "unassisted"
mergers. During 2007-10, 270 commercial banks and 54 savings
institutions, representing 4 percent of commercial banks and sav-
ings institutions in operation at the end of 2006, failed; unassisted
mergers absorbed another 893 commercial banks and 109 savings
institutions. These data refer to FDIC-insured commercial banks
and savings institutions located in U.S. states and the District of
Columbia and were obtained from Historical Statistics on Banking,
Tables CB02 and SI02 (http://www2.fdic.gov/hsob/index.asp).

David C. Wheelock is a vice president and deputy director of research at the Federal Reserve Bank of St. Louis. The author thanks Subhayu Bandyopadhyay, Alton Gilbert, and Adam Zaretsky for comments on a previous draft of this article. David A. Lopez provided research assistance.

(C) 2011, The Federal Reserve Bank of St. Louis. The views expressed in this article are those of the author(s) and do not necessarily reflect the views of the Federal Reserve System, the Board of Governors, or the regional Federal Reserve Banks. Articles may be reprinted, reproduced, published, distributed, displayed, and transmitted in their entirety if copyright notice, author name(s), and full citation are included. Abstracts, synopses, and other derivative works may be made only with prior written permission of the Federal Reserve Bank of St. Louis. 
early 1990s toward greater concentration of total U.S. deposits among the largest banks. ${ }^{2}$

Federal law prohibits any bank from obtaining more than 10 percent of total U.S. deposits or more than 30 percent of a single state's total deposits by acquiring other non-failed banks, and some states have imposed even lower deposit share limits. ${ }^{3}$ Further, antitrust enforcement prevents mergers of non-failed banks that would significantly increase the concentration of local banking markets. However, antitrust policy does not (i) prevent acquisitions of failed banks that increase local market concentration or (ii) attempt to limit increases in concentration that do not result from mergers. Nonetheless, during the 1990s, local urban banking markets generally did not become significantly more concentrated, despite increases in the deposit shares of the largest U.S. and regional banks (Amel, 1996, and Dick, 2006).

Banking industry consolidation has since continued, spurred in part by the recent financial crisis and recession. This article examines changes since 1999 in the concentration of U.S. banking markets, defined both at the local level (metropolitan statistical areas [MSAs] and nonMSA rural counties) and at the Census-region level. It examines whether the characteristics of urban and regional banking markets observed during the 1990s continued over the subsequent decade. The article focuses in particular on the years 2006-10 to gauge whether trends in banking market structures continued during the financial crisis and recession. The resolution of failed banks during 2007-10 did not increase the concentration of most local banking markets (Wheelock, 2011). However, unassisted mergers accounted for more of the decline in the number of U.S. banks during 2007-10 than did bank failures, and therefore

\footnotetext{
2 In both 1984 and 1993, the 10 largest banks held 15 percent of total U.S. bank deposits. However, by 1999, the 10 largest banks held 28 percent of total U.S. bank deposits. These data are for December 31 of the year indicated for U.S. commercial banks located in the 50 states and the District of Columbia.

3 Caps on deposit shares were imposed by the Riegle-Neal Interstate Banking and Branching Efficiency Act of 1994. Adequately capitalized banks may exceed the caps by acquiring failing or FDICassisted banks. Banks may also exceed the caps through internally generated growth. See Spong (2000) for additional details.
}

potentially had a larger impact on the structures of banking markets.

Following the approach of Dick (2006), this article uses both the Herfindahl-Hirschman index (HHI) and the number of dominant firms in a market-that is, the minimum number of banks that, combined, hold at least 50 percent of a market's total deposits-to measure market concentration. However, unlike Dick (2006), this article examines trends in the concentration of rural banking markets as well as MSAs, and it includes both commercial banks and savings institutions in the analysis of market concentration (for comparison, the article also reports results for commercial banks only). ${ }^{4}$ Further, the article investigates the impact of unassisted mergers on banking market concentration during 2007-10. The results show that, in general, local banking markets did not become significantly more concentrated during 2006-10 but, as Dick (2006) finds for the 1990s, concentration increased markedly at the level of U.S. Census regions.

The next section investigates trends in bank deposit concentration for both local banking markets (MSAs and rural counties) and Census regions. The following section examines trends in the number of dominant banks, again at the levels of local banking markets and Census regions. Subsequently, the article examines the impact of unassisted mergers during 2007-10 on the concentration of deposits for MSAs and rural counties. The final section provides study conclusions.

\section{BANKING CONCENTRATION: LOCAL AND REGIONAL PATTERNS}

The recent decline in the number of U.S. banks has continued a trend dating back to the mid-1980s (Figure 1). Hundreds of banks failed in the late 1980s and early 1990s. Many more were absorbed through unassisted mergers, spurred by the relaxation of legal restrictions on bank

\footnotetext{
4 Regulators consider the presence of savings institutions when evaluating the implications of proposed bank mergers on market competition but down-weight the shares of deposits held by savings institutions by one-half in formal analysis of market concentration. See Gilbert and Zaretsky (2003) for analysis of the methods and assumptions used by regulators in evaluating banking market competition.
} 


\section{Figure 1}

\section{Number of U.S. Commercial Banks and Savings Institutions (1984-2010)}

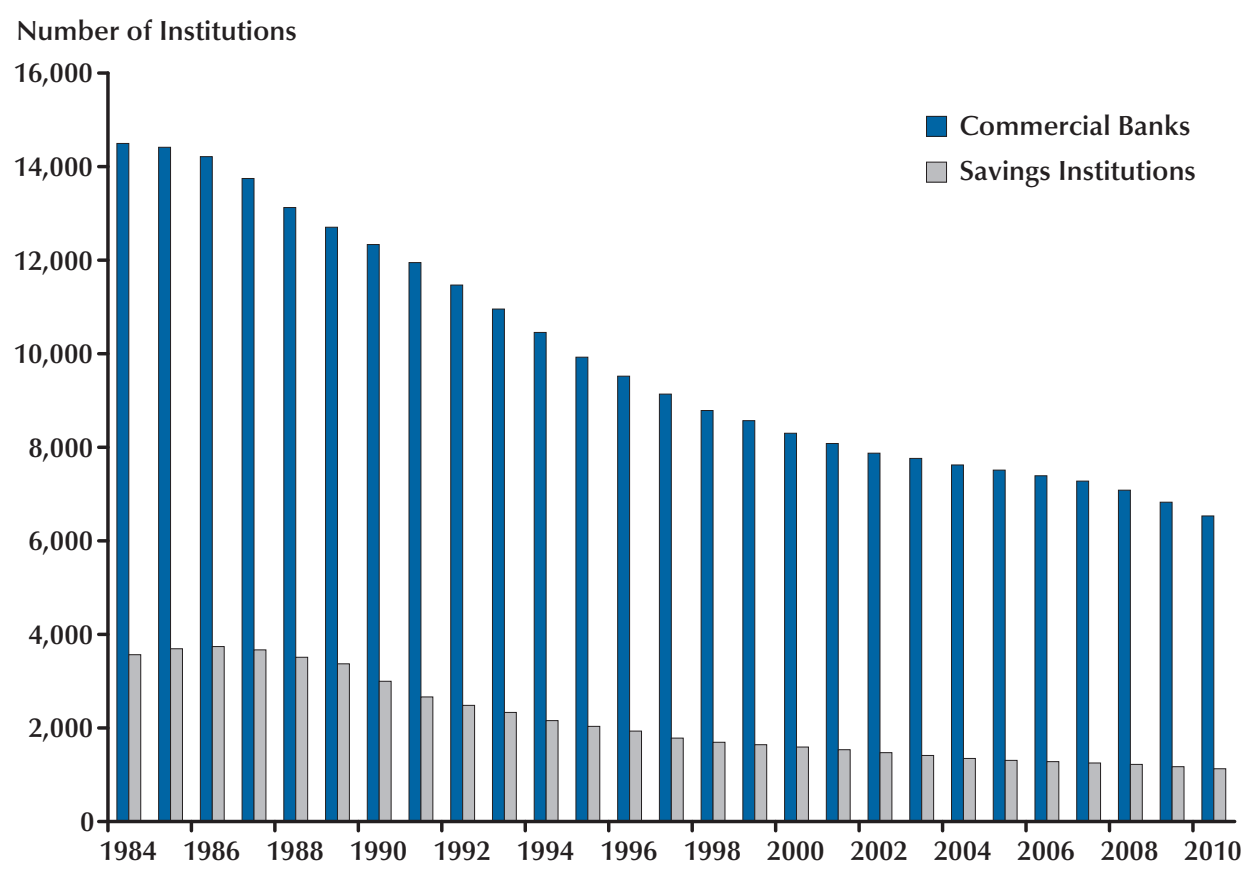

branching by many states and the federal government (Amel, 1996). ${ }^{5}$ The number of U.S. commercial banks reached a post-World War II peak of 14,495 banks in 1984. By the end of 2010, the number had fallen to 6,532. Similarly, the number of Federal Deposit Insurance Corporation (FDIC)insured savings institutions fell from 3,566 to 1,128 over the same period (the number of savings institutions peaked at 3,740 in 1986).

Despite an increase in the share of total U.S. deposits held by the very largest banks, the concentration of deposits among banks in local markets changed little, on average, from the mid-1980s through the 1990s (Amel, 1996, and Dick, 2006). Furthermore, the advent of interstate bank branching in 1997 had little immediate impact on either

\footnotetext{
5 The Riegle-Neal Interstate Banking and Branching Efficiency Act of 1994 permitted interstate branching beginning in 1997 but gave states the option to restrict de novo branching by banks headquartered in other states. The Dodd-Frank Wall Street Reform and Consumer Protection Act of 2010 (Section 613) substantially removed remaining restrictions on interstate branching by eliminating this option.
}

local banking market concentration or state-level measures of banking market competition (Dick, 2006, and Yildirim and Mohanty, 2010). ${ }^{6}$

Bank regulators use Department of Justice (DOJ) guidelines for market concentration to evaluate the competitive effects of proposed bank mergers and acquisitions. Proposed transactions that would substantially increase market concentration are subject to more scrutiny and are more likely to be rejected on antitrust grounds than transactions that would not increase concentration significantly. Regulators use data on deposits held by individual bank branch offices, which banks are required to report on June 30 of each year, to measure the concentration of local banking markets. ${ }^{7}$

6 Yildirim and Mohanty (2010) find that state banking markets could be characterized as monopolistically competitive both before and after deregulation; however, they also find that the level of competition declined in 30 states after deregulation, increased in 10 states, and did not change significantly in 10 others.

7 Summary of Deposits data are available from the FDIC (http://ww2.fdic.gov/sod/index.asp). 
Ordinarily, proposed mergers are not challenged on competitive grounds unless they would result in a post-merger HHI value of more than 1800 points and an increase in the index of more than 200 points in the relevant banking market. ${ }^{8}$

A premise of antitrust enforcement is that banking markets are local in nature, and regulators calculate pro forma HHI values for local banking markets (typically MSAs or non-MSA rural counties) to evaluate the competitive implications of proposed bank mergers. ${ }^{9}$ In the past, legal restrictions on branching and high transportation and communications costs made it difficult and costly for the public to obtain services from geographically distant banks. Further, many studies found that deposit interest rates were lower, and loan interest rates were higher, in more concentrated local banking markets, suggesting that concentration was an important determinant of the competitiveness of banking markets. ${ }^{10}$ However, branching deregulation, along with advances in informationprocessing and communications technologies, have reduced the cost of obtaining financial services from distant banks and raise the question whether larger geographic areas, such as states, Census regions, or even the nation as a whole, are more relevant for evaluating banking competition. Nonetheless, studies find that (i) households and small businesses, to a substantial degree, continue to obtain their financial services from

8 The HHI is calculated as the sum of the squared market shares of each firm competing in a market-that is, $\mathrm{HHI}=\Sigma_{i}$ market $_{\text {share }}^{2}$, where there are $i=1, \ldots, n$ firms in the market and market share ${ }_{i}$ is the percentage of market output (deposits in the present context) produced by the $i$ th firm. Guidelines for the use of the HHI in antitrust enforcement are established by the DOJ

(www.justice.gov/atr/public/guidelines/6472.htm).

9 Regulators have defined some U.S. banking markets over larger geographic areas, such as multiple counties, and occasionally they redefine markets based on changes in commuting patterns, trade areas, transportation networks, and so forth. Current definitions for all U.S. banking markets are available from the Federal Reserve Bank of St. Louis (http://cassidi.stlouisfed.org/).

10 The relationship between concentration and competition is potentially ambiguous. For example, if barriers to entry and exit are sufficiently low, then even a monopolist will not earn excess profits in the long run because other firms will enter and drive down the market price if the incumbent firm sets its price above marginal cost (Baumol, Panzar, and Willig, 1988). See Berger et al. (2004) for further discussion of the relationship between market concentration and competition and a review of recent research on the determinants and effects of concentration and competition in banking. banks located in their communities ${ }^{11}$ and (ii) the structure of local banking markets continues to affect the level of competition within those markets. For example, Hannan and Prager (2004) find that banks that operate in a single MSA or nonMSA county market offer lower deposit interest rates when those markets are more concentrated. However, the study also finds that the relationship between local concentration and deposit interest rates is weaker in markets where the share of banks operating in more than one market is higher. Still, the authors conclude that market structure continues to influence the competitive behavior of banks operating in local markets.

Dick (2006) investigates whether the level of bank concentration changed significantly between 1993 and 1999 across MSAs and Census regions to assess the impact on banking market concentration of the removal of most restrictions on interstate branching in 1997. She finds that the mean and median HHI values for MSAs declined slightly between 1993 and 1999, whereas HHI values increased for all nine Census regions, with the percentage increases ranging from 17 percent in the Pacific region to 421 percent in the South Atlantic region.

\section{Local Market Concentration}

The patterns that Dick (2006) observes for 1993-99 continued in later years. Table 1 reports summary information about the distribution of HHI values across MSAs in 1999, 2006, and 2010. The values reported in Panel A of Table 1 are based on total deposits data for commercial banks only, as in Dick (2006), whereas those reported in Panel B are based on data for both commercial banks and savings institutions. ${ }^{12}$ The information in Panel A shows that both mean and median HHI values declined by more than 100 points between

\footnotetext{
${ }^{11}$ See Gilbert and Zaretsky (2003) for references to these studies.

${ }^{12}$ All subsequent tables in this article are divided similarly: Information reported in Panel A is based on data for commercial banks only, whereas information reported in Panel B is based on data for both commercial banks and savings institutions. Bank regulators usually weight the deposits of savings institutions by 0.5 in calculating $\mathrm{HHI}$ values to measure the concentration of banking markets. However, this article assigns them full weight but also presents results based on data that exclude savings institution deposits altogether.
} 


\section{Table 1}

\section{Descriptive Statistics for the HHI (MSAs)}

\begin{tabular}{|c|c|c|c|}
\hline Bank type & 1999 & 2006 & 2010 \\
\hline \multicolumn{4}{|c|}{ Panel A (commercial banks) } \\
\hline No. of markets & 361 & 361 & 366 \\
\hline Minimum & 516 & 515 & 539 \\
\hline Maximum & 8006 & 8346 & 6666 \\
\hline Mean & 1911.8 & 1760.7 & 1703.8 \\
\hline Q1 & 1375 & 1255 & 1188 \\
\hline Median & 1746 & 1588 & 1459 \\
\hline Q3 & 2198 & 1971 & 1902 \\
\hline Standard deviation & 905.92 & 867.02 & 860.39 \\
\hline \multicolumn{4}{|c|}{ Panel B (commercial banks and savings institutions) } \\
\hline No. of markets & 361 & 361 & 366 \\
\hline Minimum & 374 & 408 & 488 \\
\hline Maximum & 5726 & 8145 & 7247 \\
\hline Mean & 1530.6 & 1527.1 & 1535.8 \\
\hline Q1 & 1139 & 1089 & 1089 \\
\hline Median & 1439 & 1346 & 1318 \\
\hline Q3 & 1750 & 1705 & 1689 \\
\hline Standard deviation & 626.25 & 835.85 & 841.60 \\
\hline
\end{tabular}

NOTE: Q1 is the first quartile of the distribution of the data; Q3 is the third quartile. Five cities were defined as MSAs between June 30, 2006, and June 30, 2010: Lake Havasu (AZ) and Palm Coast (FL) were designated as MSAs in December 2006; Cape Girardeau (MO), Manhattan (KS), and Mankato-North Mankato (MN) were designated as MSAs in November 2008.

1999 and 2006 for commercial banks, whereas the information in Panel B shows that median HHI values declined by 93 points and mean HHI values declined by 4 points for commercial banks and savings institutions. ${ }^{13}$ Thus, for commercial banks, the decline in mean and median HHI values between 1993 and 1999 at the MSA level noted by Dick (2006) continued through 2006. Further, these trends also continued during 200710, despite the financial crisis and recession and resulting wave of bank failures and mergers.

Table 2 reports similar information for nonMSA (i.e., "rural”) banking markets. Rural banking markets generally are more concentrated than urban markets. For example, the median HHI value for non-MSA counties in 2010 was 3195 (based on data for commercial banks only), whereas the median HHI value for MSAs was

\footnotetext{
${ }^{13}$ Many commercial banks and savings institutions are controlled by bank (or thrift) holding companies, which may have a controlling interest in more than one bank in a given market. Bank regulators and the DOJ consider common control of multiple banks in a market when evaluating proposed bank mergers. However, in this article no adjustment is made for common control of multiple banks in a market in calculating measures of market concentration, which seems consistent with Dick's (2006) approach. Although failing to adjust for common ownership would tend to lead to understatement of the HHI, on average, holding companies have increasingly tended to merge their multiple bank subsidiaries into a single bank, which lessens this bias in more recent years and, more importantly, would tend to upwardly bias the unadjusted changes in HHI over time. Hence, on average, increases in unadjusted HHI likely overstate the extent to which concentration has increased. Since the observed increases in unadjusted HHI in local banking markets have been small, on average, the average increase in concentration taking account of common control of multiple banks in a market would likely be even smaller.
} 
Table 2

Descriptive Statistics for the HHI (Non-MSA Rural Counties)

\begin{tabular}{|c|c|c|c|}
\hline Bank type & 1999 & 2006 & 2010 \\
\hline \multicolumn{4}{|c|}{ Panel A (commercial banks) } \\
\hline No. of markets & 2023 & 2024 & 2015 \\
\hline Minimum & 830 & 891 & 839 \\
\hline Maximum & 10000 & 10000 & 10000 \\
\hline Mean & 4032.6 & 3821.5 & 3791.6 \\
\hline Q1 & 2405 & 2268 & 2243 \\
\hline Median & 3399 & 3199 & 3195 \\
\hline Q3 & 5054 & 4831 & 4740 \\
\hline Standard deviation & 2274.11 & 2187.70 & 2171.10 \\
\hline \multicolumn{4}{|c|}{ Panel B (commercial banks and savings institutions) } \\
\hline No. of markets & 2027 & 2026 & 2017 \\
\hline Minimum & 739 & 735 & 704 \\
\hline Maximum & 10000 & 10000 & 10000 \\
\hline Mean & 3684.3 & 3587.8 & 3594.9 \\
\hline Q1 & 2143 & 2073 & 2126 \\
\hline Median & 3010 & 2955 & 2965 \\
\hline Q3 & 4558 & 4392 & 4405 \\
\hline Standard deviation & 2236.58 & 2153.05 & 2144.41 \\
\hline
\end{tabular}

1459. However, as with MSA markets, mean and median HHI values for rural markets declined between 1999 and 2010. Thus, in mid-2010, the mean and median concentrations of both MSA and rural banking markets were substantially lower than in 1999 (and in 1993 for MSA markets) even though there were far fewer banks and savings institutions in the United States in 2010 than in either 1993 or 1999.

\section{Regional Concentration}

That the substantial reduction in the number of banks in the United States from the 1990s through 2010 did not increase the average concentration of local banking markets is consistent with the active enforcement of antitrust policy by bank regulators and the DOJ, whose officials generally deny bank merger applications that would substantially increase the concentration of local banking markets. However, antitrust policy is not applied in banking over larger geographic areas, such as Census regions (though, as noted previously, federal law prohibits individual banks from holding more than 10 percent of total U.S. bank deposits, or 30 percent of a state's total deposits, if that level of deposits is obtained through acquisitions of non-failed banks). Dick (2006) finds that HHI values increased substantially between 1993 and 1999 for all nine U.S. Census regions.

Table 3 reports HHI values for U.S. Census regions for 1999, 2006, and 2010. ${ }^{14} \mathrm{HHI}$ values vary widely across U.S. Census regions. For 2010, HHI values range from 341 for the East South

\footnotetext{
${ }^{14}$ Dick's (2006) data exclude savings institutions and rural market deposits. By contrast, the information reported in Table 3 is based on data that include both MSA and rural deposits. However, HHI values and trends are not qualitatively different from those reported in Table 3 if rural deposits are excluded from the analysis.
} 


\section{Table 3}

\section{HHI Values (Census Regions)}

\begin{tabular}{|c|c|c|c|}
\hline Census region & 1999 & 2006 & 2010 \\
\hline \multicolumn{4}{|c|}{ Panel A (commercial banks) } \\
\hline New England & 1419 & 1194 & 1377 \\
\hline Middle Atlantic & 577 & 914 & 997 \\
\hline East North Central & 135 & 284 & 381 \\
\hline West North Central & 167 & 712 & 554 \\
\hline South Atlantic & 589 & 845 & 639 \\
\hline East South Central & 233 & 297 & 341 \\
\hline West South Central & 285 & 501 & 508 \\
\hline Mountain & 370 & 645 & 796 \\
\hline Pacific & 1295 & 1155 & 1183 \\
\hline \multicolumn{4}{|c|}{ Panel B (commercial banks and savings institutions) } \\
\hline New England & 571 & 539 & 669 \\
\hline Middle Atlantic & 371 & 618 & 718 \\
\hline East North Central & 101 & 226 & 315 \\
\hline West North Central & 145 & 631 & 492 \\
\hline South Atlantic & 473 & 600 & 517 \\
\hline East South Central & 215 & 277 & 319 \\
\hline West South Central & 229 & 416 & 446 \\
\hline Mountain & 310 & 723 & 650 \\
\hline Pacific & 784 & 781 & 1069 \\
\hline
\end{tabular}

NOTE: U.S. Census regions include the following states: New England (CT, ME, MA, NH, RI, VT); Middle Atlantic (NJ, NY, PA); East North Central (IN, IL, MI, OH, WI); West North Central (IA, KS, MN, MO, NE, ND, SD); South Atlantic (DE, DC, FL, GA, MD, NC, SC, VA, WV); East South Central (AL, KY, MS, TN); West South Central (AR, LA, OK, TX); Mountain (AZ, CO, ID, NM, MT, UT, NV, WY); and Pacific (AK, CA, HI, OR, WA).

Central region to 1377 for the New England region (Panel A). However, regional HHI values increased between 1999 and 2010 in each region except the New England and the Pacific regions, with the largest increases occurring between 1999 and 2006. When savings institutions are included in the analysis (Panel B), the interregional range of HHI values was narrower. In addition, $\mathrm{HHI}$ values rose between 1999 and 2010 in all regions. Thus, regardless of whether savings institutions are included in the analysis, HHI values increased in most, if not all, regions, indicating increased concentration at the regional level. Further, in most regions, a higher percentage of the increase in HHI values occurred during 1999-2006 than during 2006-10. Thus, the financial crisis and recession did not generally cause a substantial increase in banking concentration, as reflected in HHI values, at either local or regional levels.

\section{DOMINANT AND FRINGE FIRMS}

In addition to changes in market concentration, Dick (2006) also investigates changes over time in the number of "dominant" and "fringe" banks in urban and regional banking markets. She defines dominant banks as the smallest set of banks that jointly hold at least half of a market's total deposits. All other banks in a market are fringe banks. Similarly, regionally dominant banks 


\section{Table 4}

\section{Descriptive Statistics for the Number of Dominant Banks (MSAs)}

\begin{tabular}{|c|c|c|c|}
\hline Bank type & 1999 & 2006 & 2010 \\
\hline \multicolumn{4}{|c|}{ Panel A (commercial banks) } \\
\hline No. of markets & 361 & 361 & 366 \\
\hline Minimum & 1 & 1 & 1 \\
\hline Maximum & 8 & 7 & 7 \\
\hline Mean & 2.7 & 2.9 & 3.0 \\
\hline Q1 & 2 & 2 & 2 \\
\hline Median & 3 & 3 & 3 \\
\hline Q3 + - n & 3 & 3 & 3 \\
\hline Standard deviation & 0.91 & 1.03 & 1.03 \\
\hline \multicolumn{4}{|c|}{ Panel B (commercial banks and savings institutions) } \\
\hline No. of markets & 361 & 361 & 366 \\
\hline Minimum & 1 & 1 & 1 \\
\hline Maximum & 11 & 9 & 7 \\
\hline Mean & 3.2 & 3.3 & 3.2 \\
\hline Q1 & 3 & 3 & 3 \\
\hline Median & 3 & 3 & 3 \\
\hline Q3 & 4 & 4 & 4 \\
\hline Standard deviation & 1.08 & 1.14 & 1.07 \\
\hline
\end{tabular}

NOTE: Q1 is the first quartile of the distribution of the data; Q3 is the third quartile. Five cities were defined as MSAs between June 30, 2006, and June 30, 2010: Lake Havasu (AZ) and Palm Coast (FL) were designated as MSAs in December 2006; Cape Girardeau (MO), Manhattan (KS), and Mankato-North Mankato (MN) were designated as MSAs in November 2008.

are those that jointly hold at least half of a region's total deposits. Dick (2006) finds that most urban markets had two or three dominant banks in both 1993 and 1999. Further, the average number of fringe banks fell slightly (from 19 banks to 18 banks), but the median number of fringe banks was 11 banks in both years.

Table 4 reports summary statistics on the number of dominant banks across MSAs for 1999, 2006, and 2010. ${ }^{15}$ The mean and median number of dominant banks, based on data for only commercial banks or for both commercial banks and savings institutions, changed little between 1999 and 2010. The ranges also varied little across time.

${ }^{15}$ As in calculating the HHI, this article makes no adjustments for cases in which a single owner has a controlling interest in more than one bank in a given market in calculating the number of dominant banks in that market (see footnote 13).
Table 5 shows the frequency distribution of the number of dominant banks for each year. In 1999, 15 (of 361) MSAs had only one dominant bank (Panel A). That number had increased slightly by 2010, when 23 (of 366) MSAs had only one dominant bank. However, the number of MSAs with four or more dominant banks also increased over time, from 48 (of 361) in 1999 to 86 (of 366) in 2010.

As shown in Panel B of Table 4, the mean number of dominant banks in MSA markets is slightly larger if savings institutions are included in the analysis, but the median remains at three banks from 1999 to 2010 and the mean and median numbers changed little between 1999 and 2010. Furthermore, the number of markets with four or more dominant banks increased from 107 (of 361) in 1999 to 124 (of 366) in 2010 (see Table 5). Hence, 


\section{Table 5}

\section{Distribution of the Number of Dominant Banks (MSAs)}

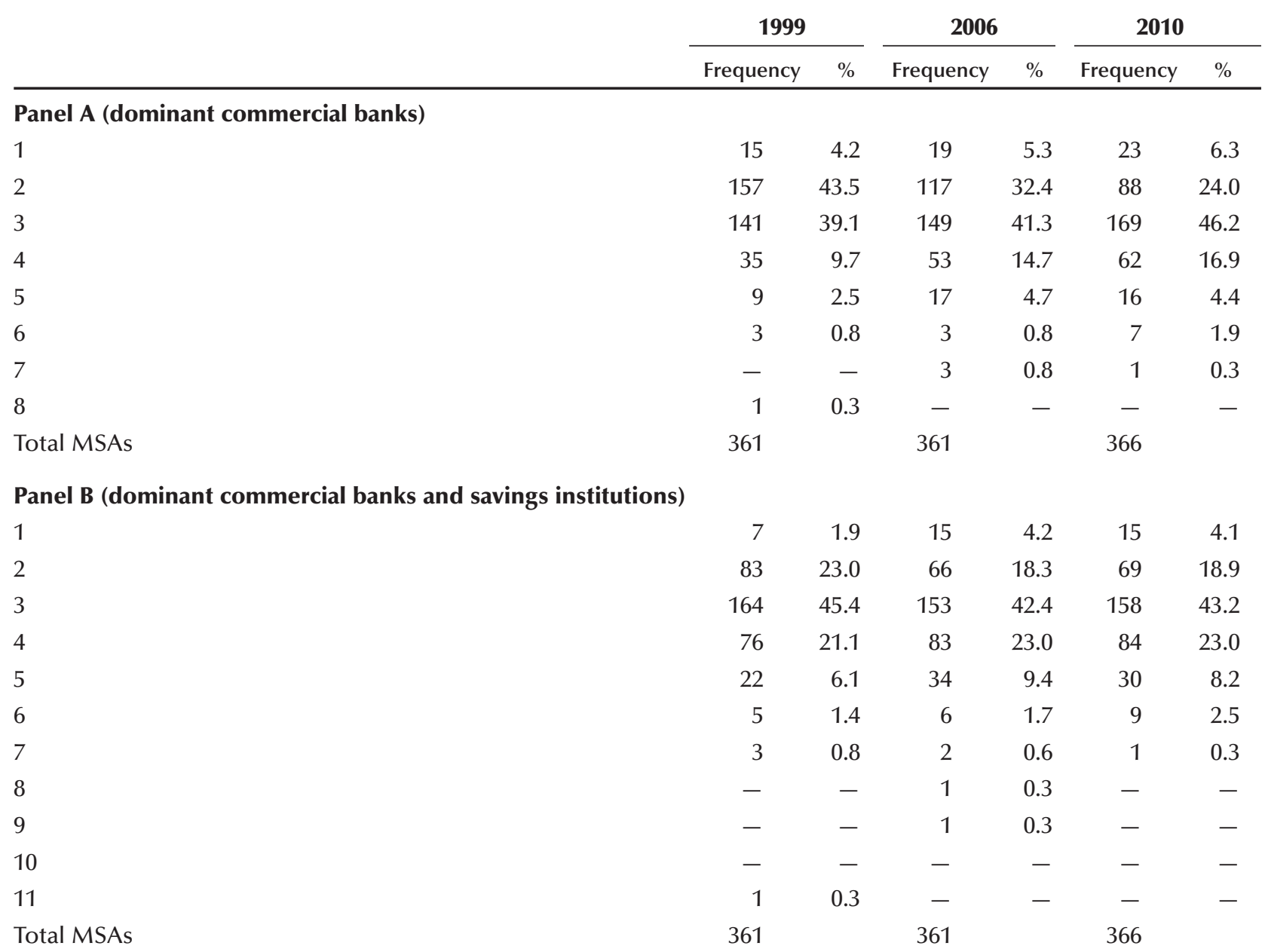

NOTE: Five cities were defined as MSAs between June 30, 2006, and June 30, 2010: Lake Havasu (AZ) and Palm Coast (FL) were designated as MSAs in December 2006; Cape Girardeau (MO), Manhattan (KS), and Mankato-North Mankato (MN) were designated as MSAs in November 2008.

the results indicate that the decline in the number of banks in the United States since 1999 has not caused the number of dominant banks in most MSA banking markets to fall.

Rural (non-MSA) banking markets tend to be more concentrated than urban banking markets. Furthermore, Wheelock (2011) finds that acquisitions of failed banks by in-market competitors resulted in substantial increases in concentration in some rural banking markets during 2007-10 but no significant increases in any large urban markets. Table 6 reports information on the num- ber of dominant banks in rural markets in 1999, 2006, and 2010. The mean and median numbers of dominant banks in rural markets are smaller than those of MSA markets, reflecting the tendency toward greater deposit concentration of rural banking markets. However, as with MSAs, the distributions of dominant banks in rural markets changed little between 1999 and 2010 (Table 7). Thus, as reflected in both HHI values and the distributions of dominant banks, and regardless of whether savings institutions are included in the analysis, the market structure of 
Table 6

Descriptive Statistics for the Number of Dominant Banks (Non-MSA Rural Counties)

\begin{tabular}{|c|c|c|c|}
\hline & 1999 & 2006 & 2010 \\
\hline \multicolumn{4}{|c|}{ Panel A (commercial banks) } \\
\hline No. of markets & 2023 & 2024 & 2015 \\
\hline Minimum & 1 & 1 & 1 \\
\hline Maximum & 5 & 5 & 5 \\
\hline Mean & 1.7 & 1.8 & 1.8 \\
\hline Q1 & 1 & 1 & 1 \\
\hline Median & 2 & 2 & 2 \\
\hline Q3 & 2 & 2 & 2 \\
\hline Standard deviation & 0.69 & 0.73 & 0.74 \\
\hline \multicolumn{4}{|c|}{ Panel B (commercial banks and savings institutions) } \\
\hline No. of markets & 2027 & 2026 & 2017 \\
\hline Minimum & 1 & 1 & 1 \\
\hline Maximum & 6 & 5 & 6 \\
\hline Mean & 1.9 & 1.9 & 1.9 \\
\hline Q1 & 1 & 1 & 1 \\
\hline Median & 2 & 2 & 2 \\
\hline Q3 & 2 & 2 & 2 \\
\hline Standard deviation & 0.77 & 0.80 & 0.78 \\
\hline
\end{tabular}

NOTE: Q1 is the first quartile of the distribution of the data; $\mathrm{Q} 3$ is the third quartile.

\section{Table 7}

Distribution of the Number of Dominant Banks (Non-MSA Rural Counties)

\begin{tabular}{|c|c|c|c|c|c|c|}
\hline & \multicolumn{2}{|l|}{1999} & \multicolumn{2}{|c|}{2006} & \multicolumn{2}{|l|}{2010} \\
\hline & Frequency & $\%$ & Frequency & $\%$ & Frequency & $\%$ \\
\hline \multicolumn{7}{|c|}{ Panel A (dominant commercial banks) } \\
\hline 1 & 835 & 41.28 & 780 & 38.54 & 788 & 39.11 \\
\hline 2 & 962 & 47.55 & 960 & 47.43 & 947 & 47.00 \\
\hline 3 & 202 & 9.99 & 247 & 12.20 & 242 & 12.01 \\
\hline 4 & 22 & 1.09 & 34 & 1.68 & 35 & 1.74 \\
\hline 5 & 2 & 0.10 & 3 & 0.15 & 3 & 0.15 \\
\hline Total rural markets & 2023 & & 2024 & & 2015 & \\
\hline \multicolumn{7}{|c|}{ Panel B (dominant commercial banks and savings institutions) } \\
\hline 1 & 699 & 34.48 & 694 & 34.25 & 705 & 34.95 \\
\hline 2 & 979 & 48.30 & 927 & 45.76 & 951 & 47.15 \\
\hline 3 & 298 & 14.70 & 354 & 17.47 & 306 & 15.17 \\
\hline 4 & 46 & 2.27 & 40 & 1.97 & 49 & 2.43 \\
\hline 5 & 3 & 0.15 & 11 & 0.54 & 5 & 0.25 \\
\hline 6 & 2 & 0.10 & - & - & 1 & 0.05 \\
\hline Total rural markets & 2027 & & 2026 & & 2017 & \\
\hline
\end{tabular}




\section{Table 8}

\section{Number of Regional Dominant Banks by Census Region}

Census region 1999

Panel A (commercial banks)

New England

Middle Atlantic

East North Central

West North Central

South Atlantic

East South Central

West South Central

Mountain

Pacific

\section{Panel B (commercial banks and savings institutions)}

New England

Middle Atlantic

East North Central

West North Central

South Atlantic

East South Central

West South Central

Mountain

Pacific
1999

2006

2010

2
7
25
58
8
14
16
9
3

$\begin{array}{rr}3 & 3 \\ 5 & 5 \\ 13 & 9 \\ 20 & 11 \\ 4 & 5 \\ 13 & 15 \\ 8 & 8 \\ 6 & 5 \\ 3 & 3\end{array}$

$\begin{array}{rrr}9 & 8 & 6 \\ 11 & 7 & 6 \\ 35 & 17 & 12 \\ 64 & 27 & 15 \\ 13 & 7 & 7 \\ 16 & 15 & 16 \\ 20 & 11 & 9 \\ 12 & 5 & 6 \\ 5 & 5 & 4\end{array}$

most local U.S. banking markets did not change substantially between 1999 and 2010, despite continued consolidation of the banking industry as a whole. ${ }^{16}$

\section{Regionally Dominant Banks}

Dick (2006) finds that the number of regionally dominant banks declined by an average of 55 percent across Census regions from 1993 to 1999. Table 8 reports on the number of regionally dominant banks in each Census region for 1999, 2006, and 2010. As shown in the table, the pattern identified by Dick (2006) continued over the subsequent decade in most regions, especially when savings institutions are included in the analysis (Panel B). ${ }^{17}$ The decline in the number of regionally dominant banks was especially pronounced

${ }^{16}$ Similarly, the average number of fringe banks did not change substantially over time in either MSA or rural banking markets.
${ }^{17}$ Dick (2006) does not include savings institutions in her analysis. She apparently also includes only banks located in MSAs in her analysis of regionally dominant banks. The exclusion of rural banks and bank branches has a larger impact on the calculation of the number of regionally dominant banks in regions with higher percentages of deposits held outside MSAs. The West North Central region had the highest percentage of bank deposits held outside MSAs in 1999 at 38 percent. If rural banks are excluded from the analysis, the West North Central region had 13, rather than 58, regionally dominant banks in 1999 (the omission of savings institutions has a much smaller impact on the number of regionally dominant banks). By contrast, in regions with a high percentage of deposits held in MSAs, the omission of rural deposits has a much smaller impact on the number of regionally dominant banks. The Pacific region had the smallest percentage of deposits held outside MSAs in 1999. If rural banks are omitted from the analysis, the number of regionally dominant banks remains three. 
Table 9

MSA and Regionally Dominant Banks by Census Region

\begin{tabular}{|c|c|c|c|c|c|c|}
\hline \multirow[b]{2}{*}{ Census region } & \multicolumn{3}{|c|}{$\begin{array}{c}\text { Mean No. of } \\
\text { MSA-dominant banks }\end{array}$} & \multicolumn{3}{|c|}{$\begin{array}{c}\text { Mean No. of } \\
\text { MSA- and regionally } \\
\text { dominant banks in MSAs }\end{array}$} \\
\hline & 1999 & 2006 & 2010 & 1999 & 2006 & 2010 \\
\hline \multicolumn{7}{|c|}{ Panel A (commercial banks) } \\
\hline New England & 1.8 & 1.8 & 1.9 & 0.8 & 1.1 & 1.3 \\
\hline Middle Atlantic & 2.6 & 2.5 & 2.5 & 0.9 & 0.6 & 0.8 \\
\hline East North Central & 2.6 & 2.9 & 3.0 & 1.2 & 1.3 & 1.5 \\
\hline West North Central & 3.2 & 3.6 & 3.6 & 2.1 & 1.9 & 1.6 \\
\hline South Atlantic & 2.8 & 2.9 & 3.0 & 1.4 & 1.5 & 1.8 \\
\hline East South Central & 3.0 & 3.4 & 3.2 & 1.9 & 2.1 & 2.2 \\
\hline West South Central & 2.9 & 3.0 & 3.0 & 1.8 & 1.4 & 1.5 \\
\hline Mountain & 2.4 & 2.7 & 2.6 & 1.4 & 1.6 & 1.2 \\
\hline Pacific & 2.4 & 2.6 & 3.0 & 1.2 & 1.4 & 1.7 \\
\hline \multicolumn{7}{|c|}{ Panel B (commercial banks and savings institutions) } \\
\hline New England & 2.8 & 3.1 & 2.9 & 1.2 & 1.5 & 1.6 \\
\hline Middle Atlantic & 3.3 & 3.4 & 3.2 & 1.4 & 0.9 & 0.9 \\
\hline East North Central & 3.2 & 3.1 & 3.2 & 1.6 & 1.7 & 1.7 \\
\hline West North Central & 3.6 & 3.8 & 3.9 & 2.4 & 2.1 & 1.8 \\
\hline South Atlantic & 3.1 & 3.2 & 3.3 & 1.6 & 1.6 & 1.8 \\
\hline East South Central & 3.2 & 3.5 & 3.4 & 2.0 & 2.3 & 2.4 \\
\hline West South Central & 3.2 & 3.1 & 3.1 & 1.9 & 1.5 & 1.4 \\
\hline Mountain & 2.8 & 2.9 & 2.8 & 1.7 & 1.4 & 1.3 \\
\hline Pacific & 3.2 & 3.3 & 3.1 & 1.6 & 2.0 & 1.8 \\
\hline
\end{tabular}

in the West North Central region, where the number of regionally dominant banks fell from 58 in 1999 to 20 in 2006, and to just 11 in 2010 (Panel A). That is, in 1999, the largest 58 banks together held 50 percent of the West North Central region's deposits, but in 2006 the largest 20 banks held 50 percent of the region's deposits, and in 2010 the largest 11 banks held 50 percent of the region's deposits. The number of regionally dominant banks also fell substantially between 1999 and 2010 in the East North Central, South Atlantic, and West South Central regions. Many states in these four regions had prohibited or severely restricted branching within their borders and were among the last states to loosen their branching laws before the Riegle-Neal Interstate Banking and Branching Efficiency Act was enacted in 1994. Consequently, those states tended to have large numbers of small- and medium-sized banks and experienced more consolidation of their banking systems during the 1990s than did many states in the New England, Middle Atlantic, and Pacific regions, which had long been more open to statewide branching and were among the first to enter into regional interstate banking compacts. ${ }^{18}$

Notably, even in regions with more regionally dominant banks in 1999, the decline in the number of regionally dominant banks during 1999-

\footnotetext{
${ }^{18}$ Kroszner and Strahan (1999) and Garrett, Wagner, and Wheelock (2005) investigate the determinants of the timing of state deregulation of branching and interstate banking laws in the 1970s, 1980s, and 1990s.
} 
2006 generally was much larger than during 2006-10. For example, the number of regionally dominant banks in the West South Central region fell from 16 to 8 between 1999 and 2006 but was still 8 in 2010 (based on data for commercial banks only). Hence, the financial crisis and recession of 2007-09 apparently did not add momentum to the ongoing trend toward greater concentration of a region's bank deposits in fewer banks.

Table 9 provides further information about patterns of regionally dominant banks across regions and over time. The table reports regional averages for MSAs in 1999, 2006, and 2010 on (i) the number of MSA-dominant banks and (ii) the number of banks that are dominant in both the MSA and its region. ${ }^{19}$ As Dick (2006) finds for 1993 and 1999, the average number of dominant banks varies more across regions than it does across time within regions. For example, based on data for commercial banks only, MSAs in the New England region had an average of 1.8 dominant banks in 1999 and 2006 and 1.9 dominant banks in 2010, whereas MSAs in the West North Central region had an average of 3.2, 3.6, and 3.6 dominant banks in 1999, 2006, and 2010, respectively.

Dick (2006) also finds that the mean number of banks dominant in both an MSA and its region increased between 1993 and 1999. However, as shown in Table 9, that trend did not continue past 1999. The mean number of banks dominant at both the MSA and regional levels changed little between 1999 and 2010 in most regions, regardless of whether savings institutions are included in the analysis. Again, there was more variation across regions than over time. MSAs in the New England and Middle Atlantic regions tended to have the smallest numbers of banks that were dominant in both the MSA and its region, whereas

\footnotetext{
${ }^{19}$ Banks that are dominant both within an MSA and within the region in which the MSA is located are banks that are (i) among the group of banks holding at least 50 percent of the deposits of the MSA and (ii) among the group of banks holding at least 50 percent of the deposits of the region. For example, in 2010, the largest five banks in the St. Louis MSA held just over 50 percent of the MSA's deposits. Four of those banks were among the largest 11 banks that together held just over 50 percent of the deposits of the West North Central Census region. Hence, there were four banks in the St. Louis MSA that were dominant in both the MSA and Census region.
}

the East South Central region generally had the highest average number of such banks.

\section{IMPACT OF MERGERS ON MARKET CONCENTRATION (2007-10)}

The recent financial crisis and recession led to a wave of bank failures and mergers that contributed to the ongoing consolidation of the U.S. banking industry. As shown previously, the average concentration of local banking markets did not increase during 2006-10. This section examines the impact on specific banking markets of unassisted bank mergers during those years. Wheelock (2011) finds that acquisitions of failed banks by in-market competitors (i.e., banks that already had branches in the markets served by the failed bank) during 2007-10 did not substantially increase concentration in most local banking markets. However, such acquisitions had a substantial impact in a few, mostly rural, banking markets. This section examines the impact on market concentration of acquisitions of non-failed banks by in-market competitors during those years.

Several large unassisted mergers involving banks operating in the same local markets occurred during 2007-10. Table 10 lists the 10 largest unassisted bank mergers during 2007-10, ranked by the total deposits held by the acquired institution as of the most recent June 30 before the merger. For example, Wachovia Bank NA, which merged with Wells Fargo Bank NA in March 2010, held \$394 billion of deposits on June 30, 2009.

Although Wachovia Bank NA merged with Wells Fargo Bank NA in March 2010, the Board of Governors of the Federal Reserve System approved the application of Wells Fargo \& Company to acquire Wachovia Corporation and its subsidiaries, including Wachovia Bank NA, on October 12, 2008. Wachovia Bank and Wells Fargo Bank had offices in common in several banking markets in Arizona, California, Colorado, Nevada, and Texas. In evaluating the competitive implications of an acquisition of Wachovia Corporation by Wells Fargo, the Board of Governors used deposit and market share data for June 30, 2007 (adjusted to 


\section{Table 10 \\ Ten Largest Unassisted Bank Mergers (2007-10)}

\begin{tabular}{|c|c|c|c|c|c|}
\hline Acquired bank & Acquiring bank & $\begin{array}{l}\text { Date of holding company } \\
\text { acquisition approval }\end{array}$ & Date of merger & $\begin{array}{l}\text { Total deposits of } \\
\text { acquired bank } \\
\text { (\$ thousands) }\end{array}$ & $\begin{array}{l}\text { Total deposits of } \\
\text { acquiring bank } \\
\text { (\$ thousands) }\end{array}$ \\
\hline Wachovia Bank, NA & Wells Fargo Bank, NA & October 12, 2008 & March 20, 2010 & $394,189,000$ & $325,417,000$ \\
\hline National City Bank & PNC Bank, NA & December 15, 2008 & November 7, 2009 & $101,141,375$ & $84,171,396$ \\
\hline Wachovia Mortgage, FSB & Wachovia Bank, NA & September 29, 2006 & October 12, 2007 & $73,243,232$ & $314,850,000$ \\
\hline Countrywide Bank, FSB & Bank of America, NA & June 5, 2008 & April 27, 2009 & $63,336,672$ & $642,252,215$ \\
\hline Fifth Third Bank* & Fifth Third Bank & March 12, 2001 & September 30, 2009 & $41,454,606$ & $31,948,335$ \\
\hline Commerce Bank, NA & TD Bank, NA & March 13, 2008 & June 1, 2008 & $40,126,588$ & $28,092,910$ \\
\hline North Fork Bank & Capital One, NA & November 8, 2006 & August 1, 2007 & $38,059,484$ & $20,567,194$ \\
\hline LaSalle Bank, NA & Bank of America, NA & September 14, 2007 & October 17, 2008 & $29,594,901$ & $642,252,215$ \\
\hline Merrill Lynch Bank \& Trust Co., FSB & Bank of America, NA & November 26, 2008 & November 2, 2009 & $28,965,596$ & $817,989,321$ \\
\hline LaSalle Bank Midwest, NA & Bank of America, NA & September 14, 2007 & October 17, 2008 & $25,011,471$ & $642,252,215$ \\
\hline
\end{tabular}

NOTE: *Fifth Third Bank (Grand Rapids) and Fifth Third Bank (Cincinnati) were both subsidiaries of the Fifth Third Financial Corporation when they merged under the charter of Fifth Third Bank (Cincinnati) in 2009. Hence, Fifth Third Bank (Cincinnati) is listed as the acquirer and Fifth Third Bank (Grand Rapids) as the acquired bank. 
reflect mergers and acquisitions through October 3, 2008). ${ }^{20}$ Wachovia Bank had only small shares of most MSA banking markets in states where Wells Fargo Bank operated, and consequently the proposed acquisition would have had little impact on concentration in most markets. However, Wachovia Bank and Wells Fargo Bank both had significant market shares in a few small MSA and rural banking markets. For example, they had the two largest market shares in the Santa Cruz, California, banking market with 27 percent (Wachovia) and 19 percent (Wells Fargo) shares. However, in their application to acquire Wachovia, Wells Fargo proposed to divest one of Wachovia Bank's branches in the Santa Cruz market to an out-of market depository institution. Further, in evaluating the competitive implications of the proposed merger, the Board of Governors noted the presence of several other banks and credit unions with significant market shares in the Santa Cruz market, as well as the recent entry into the market of two other depository institutions. Hence, the Board determined that the merger would not adversely harm competition in the Santa Cruz market. ${ }^{21}$ The Board of Governors made similar determinations about the few other banking markets where both Wachovia Bank and Wells Fargo had relatively large market shares.

Although both Wachovia Bank NA and Wells Fargo Bank NA were controlled by Wells Fargo \& Company when the banks were formally merged in March 2010, an indication of the impact of the merger on concentration in the Santa Cruz and other markets is obtained by comparing deposits and market share data for June 30, 2009, and June 30, 2010. Based on data for June 30, 2009, the HHI value for the Santa Cruz MSA was 1295, indicating that the market was moderately concentrated by DOJ guidelines. Had Wachovia Bank

\footnotetext{
${ }^{20}$ The statement by the Board of Governors regarding the application by Wells Fargo \& Company to acquire Wachovia Corporation and Wachovia's subsidiary banks and non-banking companies is available on the Board's website (www.federalreserve.gov/newsevents/ press/orders/orders20081021a1.pdf).

${ }^{21}$ Credit unions are not required to report branch-level deposits data and, hence, ordinarily they are excluded from calculation of market concentration measures, such as the HHI. However, the Board may consider the presence of credit unions in a market when evaluating applications for bank mergers.
}

and Wells Fargo Bank been merged as of that date, and assuming no other differences in the market, the HHI value would have been 1832 . Hence, a simple pro forma analysis suggests that the merger would produce a larger increase in market concentration than permitted by DOJ guidelines. However, the divestiture of one of Wachovia Bank's branches in the Santa Cruz market reduced the impact of the merger on market concentration. In the event, the HHI value for the Santa Cruz market rose by only 202 points, from 1295 to 1497, between June 30, 2009, and June 30, 2010, and hence the market remained only moderately concentrated. ${ }^{22}$

The acquisition of National City Bank by PNC Bank NA in November 2009 was the secondlargest merger in terms of total deposits of the acquired bank during 2007-10. The Board of Governors approved the application of The PNC Financial Services Group, Inc. (the parent company of PNC Bank NA) to acquire National City Corporation (the parent of National City Bank) on December 15, 2008. The Board relied on deposit and market share data as of June 30, 2008 (adjusted to reflect mergers and acquisitions through November 4,2008 ) to evaluate the competitive implications of the acquisition on individual banking markets.

National City Bank and PNC Bank competed directly in 10 banking markets in Florida, Kentucky, Ohio, and Pennsylvania, and both had substantial shares of the Erie and Pittsburgh, Pennsylvania, markets. In its merger application, PNC proposed to divest several National City Bank branches in both the Pittsburgh and Erie markets. In addition, the Board of Governors determined that a substantial portion of the deposits held by PNC Bank in Pittsburgh were deposits of customers located outside the Pittsburgh market, including various municipalities and governments, and escrow accounts for mortgages and other transactions outside the market. Consequently, the Board determined that, in effect, PNC had a lower effective share of the Pittsburgh

\footnotetext{
22 The change in HHI from one year to the next reflects all transactions that occurred in a market during the year, not just the merger of Wachovia Bank and Wells Fargo Bank, as well as fluctuations in market shares associated with other deposit inflows and outflows.
} 
Table 11

Descriptive Statistics for the HHI in Overlapping Markets for Bank Mergers (2007-10)

\begin{tabular}{|c|c|c|c|c|c|c|}
\hline & \multicolumn{3}{|c|}{ MSAs } & \multicolumn{3}{|c|}{ Non-MSA rural counties } \\
\hline & HHI before* & HHI after ${ }^{+}$ & Difference $^{\ddagger}$ & HHI before* & HHI after ${ }^{+}$ & Difference $^{\ddagger}$ \\
\hline \multicolumn{7}{|c|}{ Panel A (Jan. 1, 2007-June 30, 2007) } \\
\hline No. of markets & 51 & 51 & 51 & 34 & 34 & 34 \\
\hline Minimum & 408.48 & 384.15 & -223.25 & 1121.30 & 1092.81 & -2163.01 \\
\hline Maximum & 4625.70 & 4402.45 & 635.33 & 6147.01 & 4265.75 & 1727.43 \\
\hline Mean & 1296.11 & 1327.00 & 30.89 & 2134.62 & 2358.65 & 224.03 \\
\hline Q1 & 910.27 & 891.98 & -49.77 & 1579.61 & 1760.57 & 46.96 \\
\hline Median & 1155.46 & 1114.97 & -10.25 & 1934.33 & 2204.36 & 127.08 \\
\hline Q3 & 1495.06 & 1486.63 & 65.40 & 2538.31 & 2774.86 & 321.55 \\
\hline Standard deviation & 659.00 & 705.13 & 151.71 & 935.73 & 899.10 & 598.69 \\
\hline \multicolumn{7}{|c|}{ Panel B (July 1, 2007-June 30, 2008) } \\
\hline No. of markets & 116 & 116 & 116 & 47 & 47 & 47 \\
\hline Minimum & 384.15 & 445.02 & -244.30 & 977.23 & 1007.49 & -272.30 \\
\hline Maximum & 6559.93 & 6504.27 & 1945.82 & 4590.82 & 5691.28 & 2145.23 \\
\hline Mean & 1312.70 & 1432.69 & 119.99 & 2124.46 & 2351.43 & 226.97 \\
\hline Q1 & 938.47 & 957.36 & -0.06 & 1334.08 & 1493.10 & 30.26 \\
\hline Median & 1165.13 & 1220.19 & 48.21 & 1799.53 & 1823.53 & 111.92 \\
\hline Q3 & 1450.68 & 1606.12 & 140.10 & 2773.81 & 2859.65 & 227.27 \\
\hline Standard deviation & 753.37 & 855.27 & 298.28 & 968.02 & 1123.69 & 430.44 \\
\hline \multicolumn{7}{|c|}{ Panel C (July 1, 2008-June 30, 2009) } \\
\hline No. of markets & 66 & 66 & 66 & 31 & 31 & 31 \\
\hline Minimum & 445.02 & 439.99 & -867.48 & 1113.50 & 1092.08 & -156.84 \\
\hline Maximum & 5631.98 & 5768.96 & 4684.56 & 4078.06 & 7956.74 & 3878.67 \\
\hline Mean & 1398.88 & 1474.41 & 75.53 & 1971.28 & 2309.60 & 338.32 \\
\hline Q1 & 889.74 & 922.43 & -65.89 & 1414.71 & 1493.24 & 2.68 \\
\hline Median & 1189.65 & 1190.35 & 4.73 & 1843.44 & 2074.01 & 148.49 \\
\hline Q3 & 1489.83 & 1522.02 & 49.27 & 2254.19 & 2550.92 & 374.04 \\
\hline Standard deviation & 933.90 & 1050.60 & 611.76 & 723.49 & 1331.83 & 721.43 \\
\hline \multicolumn{7}{|c|}{ Panel D (July 1, 2009-June 30, 2010) } \\
\hline No. of markets & 78 & 78 & 78 & 21 & 21 & 21 \\
\hline Minimum & 439.99 & 488.17 & -2289.39 & 943.52 & 992.73 & -421.80 \\
\hline Maximum & 6802.87 & 7246.76 & 1551.94 & 3909.51 & 7410.51 & 3501.00 \\
\hline Mean & 1462.61 & 1555.52 & 92.91 & 2100.92 & 2540.99 & 440.06 \\
\hline Q1 & 939.94 & 1033.07 & 4.67 & 1429.57 & 1542.64 & 81.51 \\
\hline Median & 1230.18 & 1296.63 & 103.94 & 1892.44 & 1896.29 & 174.93 \\
\hline Q3 & 1441.67 & 1615.89 & 225.36 & 2333.82 & 2963.18 & 470.81 \\
\hline Standard deviation & 1016.31 & 1074.24 & 397.97 & 840.29 & 1516.96 & 816.02 \\
\hline
\end{tabular}




\section{Table 11, cont'd}

\section{Descriptive Statistics for the HHI in Overlapping Markets for Bank Mergers (2007-10)}

\begin{tabular}{|c|c|c|c|c|c|c|}
\hline & \multicolumn{3}{|c|}{ MSAs } & \multicolumn{3}{|c|}{ Non-MSA rural counties } \\
\hline & HHI before* & $\mathrm{HHI}$ after ${ }^{+}$ & Difference $^{\ddagger}$ & HHI before* & HHI after ${ }^{+}$ & Difference $^{\ddagger}$ \\
\hline \multicolumn{7}{|c|}{ Panel E (Jan. 1, 2007-June 30, 2010) } \\
\hline No. of markets & 311 & 311 & 311 & 133 & 133 & 133 \\
\hline Minimum & 384.15 & 384.15 & -2289.39 & 943.52 & 992.73 & -2163.01 \\
\hline Maximum & 6802.87 & 7246.76 & 4684.56 & 6147.01 & 7956.74 & 3878.67 \\
\hline Mean & 1365.87 & 1455.02 & 89.15 & 2087.64 & 2373.46 & 285.82 \\
\hline Q1 & 925.60 & 955.38 & -25.91 & 1429.57 & 1542.64 & 38.49 \\
\hline Median & 1177.98 & 1247.80 & 31.20 & 1837.30 & 2062.67 & 134.45 \\
\hline Q3 & 1476.66 & 1600.65 & 146.01 & 2531.96 & 2719.63 & 301.14 \\
\hline Standard deviation & 851.16 & 935.48 & 394.31 & 880.71 & 1183.03 & 616.44 \\
\hline
\end{tabular}

NOTE: The summary statistics exclude all market overlaps for mergers that occurred after June 30, 2010. *HHI before" corresponds to the $\mathrm{HHI}$ value on the June 30 before the merger date; " $\mathrm{HHI}$ after" corresponds to the HHI value on the June 30 after the merger date; \#"Difference" corresponds to the change between the $\mathrm{HHI}$ value from the June 30 before the merger date and the $\mathrm{HHI}$ value on the June 30 after the merger date.

banking market than suggested by the Summary of Deposits data used in calculating market HHI values. ${ }^{23}$ Furthermore, the Board noted that a large number of banks (57) would remain in the Pittsburgh market after the merger of PNC and National City, and that 6 banking organizations had entered the Pittsburgh market during the previous 4 years. Similarly, considering the proposed branch divestitures and the presence of several other competitors, including four community credit unions, the Board determined that competition in the Erie market would not be adversely affected by PNC's acquisition of National City Bank. ${ }^{24}$

Between January 1, 2007, and June 30, 2010, unassisted bank mergers occurred in 311 MSAs and 133 rural counties where both merger part-

\footnotetext{
${ }^{23}$ Many banking organizations book the deposits of out-of-market customers at their headquarters location, which distorts market share and HHI values as measures of local market concentration, and is one reason why the Board of Governors and DOJ consider other indicators of market competition in addition to HHI values when evaluating bank merger applications.

${ }^{24}$ The order approving the merger of acquisition of National City Corporation by PNC Financial Services Group, Inc. is available on the Board of Governor's website (http://www.federalreserve.gov/ newsevents/press/orders/orders20081215a1.pdf).
}

ners had existing offices. Table 11 presents summary information about changes in HHI values from the most recent June 30 before a merger to the June 30 immediately following the merger in those markets. ${ }^{25}$ Thus, Panel A of the table reports summary statistics for HHI values on June 30, 2006, and June 30, 2007, and the difference in HHI values between those dates, for markets where mergers occurred between January 1, 2007, and June 30, 2007. Panel B reports summary statistics for HHI values on June 30, 2007, and June 30, 2008 , and the difference in HHI values between those dates, for markets where mergers occurred between July 1, 2007, and June 30, 2008. Panels C and $D$ report similar information for markets where mergers occurred between July 1, 2008, and June 30, 2009, and between July 1, 2009, and June 30, 2010, respectively. Panel E presents summary statistics for all markets where mergers occurred between January 1, 2007, and June 30, 2010.

The Board of Governors approved many of the bank mergers that occurred between January 1,

\footnotetext{
${ }^{25}$ Branch-level deposits data for June 30, 2011, are not yet available to calculate changes in HHI values in markets in which mergers occurred between July 1 and December 31, 2010.
} 
2007, and June 30, 2007, in 2006 or before. In doing so, the Board would have relied on deposits and market share information from before June 30 , 2006, when evaluating the competitive implications of those mergers. Nonetheless, comparison of HHI values based on data for June 30, 2006, and June 30, 2007, shows how mergers that occurred between January 1, 2007, and June 30, 2007, affected market concentration, regardless of when those mergers were approved. Similarly, comparison of HHI values based on data for June 30, 2007, and June 30, 2008, shows the impact of mergers that occurred between July 1, 2007, and June 30, 2008, on market concentration, regardless of when the Board of Governors approved those mergers. Hence, the data underlying the summary information reported in Table 11 include mergers that were consummated during the period indicated, regardless of when the mergers were approved.

As reported in Panel E, for MSAs, for the entire period January 1, 2007, through June 30, 2010 , the mean and median changes in HHI values over the 12-month periods during which one or more bank mergers occurred were 89 and 31 points, respectively. For individual years, the mean (median) changes range from 31 points $(-10$ points) to 120 points (104 points). The range of changes in $\mathrm{HHI}$ values was very wide, from -2289 points to 4685 points across all MSAs where one or more unassisted mergers of banks occurred between January 1, 2007, and June 30, 2010. Of course, mergers are just one cause of changes in HHI values from one year to the next. Other reasons for changes in HHI values include bank failures, de novo entry, reassignment of deposits among a bank's branches, and other changes in the distribution of deposits across banks not associated with mergers.

For rural counties over the entire period, the mean and median changes in HHI values were 286 and 134 points, respectively. For individual years, the mean (median) changes range from 224 (112) points to 440 (175) points. Hence, HHI values tended to increase more in rural counties where mergers occurred than in MSAs. In general, rural banking markets are more concentrated than urban markets. Among rural counties where mergers occurred, the mean $\mathrm{HHI}$ value before a merger was 2088 points, compared with 1366 points in MSAs. Many rural banking markets span more than one county, however, and as noted previously, banking regulators may consider the presence of credit unions and other factors that are not reflected in HHI values when evaluating the competitive effects of proposed bank mergers. Nonetheless, it appears that, on average, unassisted bank mergers during 2007-10 had a larger impact on concentration in rural counties than in MSA banking markets; Wheelock (2011) finds a similar result for mergers involving failed banks.

\section{CONCLUSION}

The number of U.S. commercial banks and savings institutions declined by 1,011, or about 12 percent, between December 31, 2006, and December 31, 2010. Unassisted mergers of nonfailed banks eliminated 1,002 banks during this period, whereas failures eliminated 324 banks (the chartering of new banks, voluntary liquidations, and other changes resulted in a net addition of 315 banks). The consolidation of the banking industry during 2007-10 continued a trend begun in the mid-1980s. Advances in informationprocessing and other technologies and the resulting economies of scale have encouraged growth in the size of banks, which deregulation of bank branching, first by states and later by the federal government, has facilitated. ${ }^{26}$

Banking industry consolidation has been marked by sharply higher shares of U.S. bank deposits held by the largest banks, as well as increased concentration of deposits measured at the level of U.S. Census regions. This article extends prior research on the structure of U.S. banking markets by investigating changes in deposit concentration at both the local and regional levels. It shows that trends toward increased concentration at the regional level in the 1990s continued through 2010. However, concentration of local banking markets has changed

\footnotetext{
${ }^{26}$ Berger (2003) discusses the implications of technological progress for the banking industry, whereas Hughes, Mester, and Moon (2001) and Wheelock and Wilson (forthcoming) report evidence of significant economies of scale in banking.
} 
little over time, even during the recent financial crisis and recession when several large bank mergers occurred. Further, the average number of banks holding at least 50 percent of deposits in a region declined over time in most U.S. Census regions, but the number holding at least 50 percent of deposits in local banking markets remained fairly constant over time. Antitrust policy is predicated on the assumption that banking markets are local in nature, and enforcement has helped keep local banking markets from becoming significantly more concentrated.

The article also examines the effects on local market concentration of mergers of banks operating in the same markets. Two of the largest mergers during 2007-10 were the merger of Wachovia Bank with Wells Fargo Bank and the merger of National City Bank with PNC Bank. In approving these applications, the Board of Governors of the Federal Reserve System noted plans to divest local branch offices and other mitigating circumstances that offset pro forma analysis of market concentration levels based on the HerfindahlHirschman Index. Further, the article finds that deposit concentration did not increase to the extent predicted by simple pro forma analysis in markets where these mergers had raised the most serious concerns about their competitive effects.
Finally, the article finds that deposit concentration did not increase substantially, on average, in local banking markets where any unassisted mergers occurred during 2007-10, though rural counties generally saw larger average increases in concentration than urban markets.

Changes in regulation and technology have reduced the cost of obtaining banking services from distant banks. However, many consumers continue to rely exclusively on local banks for financial services and evidence suggests that the pricing of banking services continues to reflect, at least in part, the structure of local banking markets. The recent financial crisis and recession did not alter the trend toward industry consolidation or change patterns of concentration at either the local or regional levels. Antitrust enforcement has ensured that the structures of local banking markets have not changed significantly as a result of unassisted mergers and acquisitions, even as the industry as a whole has consolidated and total U.S. deposits have become increasingly concentrated among the very largest banks. As technology evolves and the costs of obtaining banking services from distant providers fall further, however, local market characteristics may become less relevant for analysis of competition in banking.

\section{REFERENCES}

Amel, Dean F. “Trends in the Structure of Federally Insured Depository Institutions, 1984-94." Federal Reserve Bulletin, January 1996, 82(1), pp. 1-15.

Baumol, William J.; Panzar, John C. and Willig, Robert D. Contestable Markets and the Theory of Industry Structure. Revised Edition. San Diego: Harcourt Brace Jovanovich, 1988.

Berger, Allen N. "The Economic Effects of Technological Progress: Evidence from the Banking Industry." Journal of Money, Credit, and Banking, April 2003, 35(2), pp. 141-76.

Berger, Allen N.; Demirgüç-Kunt, Asli; Levine, Ross and Haubrich, Joseph G. "Bank Concentration and Competition: An Evolution in the Making.” Journal of Money, Credit, and Banking, June 2004, 36(3 Part 2), pp. 433-51.

Dick, Astrid A. "Nationwide Branching and Its Impact on Market Structure, Quality, and Bank Performance." Journal of Business, March 2006, 79(2), pp. 567-92.

Garrett, Thomas A.; Wagner, Gary A. and Wheelock, David C. "A Spatial Analysis of State Banking Regulation.” Papers in Regional Science, November 2005, 84(4), pp. 575-95. 


\section{Wheelock}

Gilbert, R. Alton and Zaretsky, Adam M. “Banking Antitrust: Are the Assumptions Still Valid?” Federal Reserve Bank of St. Louis Review, November/December 2003, 85(6) pp. 29-52;

http://research.stlouisfed.org/publications/review/03/11/gilbert.pdf.

Hannan, Timothy H. and Prager, Robin A. "The Competitive Implications of Multimarket Bank Branching.” Journal of Banking and Finance, August 2004, 28(8), pp. 1889-914.

Hughes, Joseph P.; Mester, Loretta J. and Moon, C.-G. "Are Scale Economies in Banking Elusive or Illusive? Evidence Obtained by Incorporating Capital Structure and Risk-Taking into Models of Bank Production.” Journal of Banking and Finance, December 2001, 25(12), pp. 2169-208.

Kroszner, Randall S. and Strahan, Philip E. "What Drives Deregulation? Economics and Politics of the Relaxation of Bank Branching Restrictions.” Quarterly Journal of Economics, November 1999, 114(4), pp. $1437-67$.

Spong, Kenneth. Banking Regulation: Its Purpose, Implementation and Effects. Fifth Edition. Kansas City, MO: Federal Reserve Bank of Kansas City, 2000; www.financialpolicy.org/regulation/spong.pdf.

Wheelock, David C. "Have Acquisitions of Failed Banks Increased the Concentration of U.S. Banking Markets?" Federal Reserve Bank of St. Louis Review, May/June 2011, 93(3), pp. 155-68; http://research.stlouisfed.org/publications/review/11/05/155-168Wheelock.pdf.

Wheelock, David C. and Wilson, Paul W. "Do Large Banks Have Lower Costs? New Estimates of Returns to Scale for U.S. Banks.” Journal of Money, Credit, and Banking, forthcoming; http://web.econ.ohio-state.edu/jmcb/jmcb/09567/09567.pdf.

Yildirim, H. Semih and Mohanty, Sunil K. "Geographic Deregulation and Competition in the U.S. Banking Industry.” Financial Markets, Institutions \& Instruments, 2010, 19(2), pp. 63-94. 